Available Online : https://proceeding.researchsynergypress.com/index.php/cset/index

RSF Conference Series: Engineering and Technology

ISSN 2809-6843 (Online) | 2809-6878 (Print)

Volume 1 Number 1 (2021): 198-203

\title{
Growth and Yield Responses of Red Onions to Different Nutrient Availability in Fertigation System
}

\author{
R.R. Rukmowati Brotodjojo', Oktavia S. Padmini², Awang H. Pratomo ${ }^{3}$ \\ 1,2 Agrotechnology Department, Universitas Pembangunan Nasional Veteran Yogyakarta, Indonesia \\ ${ }^{3}$ Information Technology Department, Universitas Pembangunan Nasional Veteran Yogyakarta, Indonesia
}

\begin{abstract}
Nutrient availability affected plant growth and yield. This study aimed to examine the effect of interval application and fertigation frequency toward plant growth and yield, and further determined the most proper fertigation interval and frequency that support the highest plant growth and yield. Experiment was arranged in Split plot randomized Completely Block Design. The main plots were interval of nutrient application, i.e., 3 days interval, 6 days interval, 9 days interval. The sub plots were the frequency of nutrient application, i.e., once/day, 2 times/day, 3 times/day. The plot size for each treatment was $2.5 \mathrm{~m} \times 1.3 \mathrm{~m}$ and plant spacing was $15 \mathrm{~cm} \times 20 \mathrm{~cm}$. Space between beds was $1 \mathrm{~m}$. Red onions (Bima variety) were planting in a raised bed covered with silver black polythene mulch. Before planting, 5 ton/ha manure and 1 ton/ha lime were mix with the soil. Fipronil 1.5\% was applied with dose $8 \mathrm{~kg} / \mathrm{ha}$ to control grubs. Nutrient was mixture between liquid organic fertilizer $(7.5 \mathrm{~mL} / \mathrm{L})$, rabbit urin $(5 \mathrm{~mL} / \mathrm{L})$ and $\mathrm{AB}$ Mix $(7.5 \mathrm{~mL} / \mathrm{L} \mathrm{A}+7.5 \mathrm{~mL}$ ) $)$. The nutrient was dispensed $150 \mathrm{~mL} / \mathrm{plant}$ according to treatment using fertigation system operated remotely using Internet of Things. The nutrient was given from 14 DAP (Days After Planting) until 68 DAP. Irrigation water was dispensed $150 \mathrm{~mL}$ daily in the same way. The interval of fertigation significantly affected the growth of red onion (plant height, number of leaves and number of yield). Three days interval of nutrient supply resulted in the tallest plant, highest number of plant leaves, and highest number of bulbs. However, the frequency of nutrient supply daily significantly affected the yield of red onion. The application of nutrient three times/day provided the highest yield (economical dry weight). Further research to examine the effect of fertigation of red onion quality is required.
\end{abstract}

Keywords: Fertigation, Growth, Red Onion, Yield

This is an open access article under the CC-BY-NC license.

\section{INTRODUCTION}

Red onion is one of important horticultural products in Indonesia. It is widely use for home cooking and food industry. Production of red onion in Indonesia were increasing during the last three years, i.e., in 2018, 2019 and 2020 were 1.503 .438 tons, 1.580 .47 tons, and 1,815,445 tons, respectively (Badan Pusat Statistik, 2021). Indonesia export red onion to Vietnam, Singapura, Malaysia, Thailand, Philippine, South Korea, and United Arab Emirates. The export red onion was fluctuated, i.e., in 2018, 2019 and 2020 were 5,227,863 $\mathrm{Kg}, 8,665,422 \mathrm{Kg}$, and $8.315 .682 \mathrm{Kg}$, respectively (Ministry of Trade, 2021). Since the price of red onion in international market is higher than domestic market, the government expects to increase the red onion export. Therefore, it is important to increase the red onion production to fulfil international market niche.

Conventionally, red onion is cultivated in raised beds with flood irrigation. This type of irrigation requires a lot of water and nutrients to support plant growth. Excess nutrients that flow with run off water will eventually polluted the water reserves. To reduce the amount of water for irrigation, drip irrigation can be applied. The efficiency of water use with drip irrigation systems can reach 80 - 95\% (Simonne et al., 2010).

Fertilizers can be incorporated into drip irrigarion system. This system called fertigation. Research showed that drip fertigation used for tomato cultivation in plastic greenhouse resulted in $101 \%$ higher water use efficiency $\left(p<0.05 ; 25 \mathrm{~kg} \mathrm{~m}^{-3}\right)$ and $296 \%$ higher partial nitrogen fertilizer productivity $(p<0.05 ; 423 \mathrm{~kg} / \mathrm{kg} \mathrm{N})$ than flood irrigation (Hu et al., 2021). This suggests drip fertigation provides more 
efficient use of water and fertilizer and thus, more environmentaly friendly. In addition, providing the appropriate nutrient will affect plant growth and yield. Red onion fertilized with granular organic fertilizer (20-30 ton/ha) produced more leaves and higher yield than those fertilized with inorganic fertilizer (187 kg/ha urea, $400 \mathrm{~kg} / \mathrm{ha}$ ZA, $311 \mathrm{~kg} / \mathrm{ha}$ SP36, $224 \mathrm{~kg} / \mathrm{ha} \mathrm{KCl)} \mathrm{(Brotodjojo} \mathrm{\&} \mathrm{Arbiwati,} \mathrm{2017).}$ Red onion produced higher bulb and dry matter yield, mean bulb size and weight when treated with microsprinkle irrigation at $1.20 \mathrm{Ep}$ and fertigation at $200 \mathrm{~kg} / \mathrm{ha}$ of NPK (100:50:50), which reduced with the reduction in amount of irrigation and fertigation (Kumar et al., 2007). Considering that plant respond differentially to nutrient availability, this research aimed to examine the interval and frequency rates of fertigation on red onion growth and yield.

\section{LITERATURE REVIEW}

Plant growth is significantly affected by the availability of nutrient. Nitrogen (N) is used for the growth of shoots and stems and leaves (Lawlor, 2002). Phosphorus (P) is used to stimulate root, fruit and seed growth (Vance et al., 2003). Meanwhile, potassium/kalium (K) is used to increase plant resistance to environmental stress, pests and diseases (Wang et al., 2013). Plant nutrient can be supplied in the form of inorganic or organic fertilizers, solid or liquid. Liquid fertilizer has several benefits over solid fertilizer, including it is easy to apply and the nutrient is easy to absorb. Liquid organic fertilizer derived from rabbit urine has a fairly high nutrient content, namely 4\% N; P205 2.8\%; and 1.2\% K20 relatively higher than the nutrient content in cattle (N 1.21\%; P2O5 0.65\%; K20 1.6\%) and goats (N 1.47\%; P2O5 0.05\%; K20 1.96\%) (Balittanah, 2006).

Inorganic fertilizer only supplies macro nutrient such as nitrogen, phosphorus and kalium, whereas organic fertilizer provides macro and micro nutrients. Combining organic and inorganic fertilizer can increase plant growth and yield. Application combination of inorganic fertilizer (N:P:K=150:80:100 $\mathrm{kg} / \mathrm{ha}$ ) and biofertilizer (Azospyrillum and PSB) resulted in the highest plant growth and yield of onion with the highest net return. The amount of inorganic fertifizer can be reduced to $75 \%$ of recommended dose and provided the highest B:C ratio (Vachan \& Tripathi, 2017). Combination of inorganic and liquid organic fertilizer can be customized to increase yield of red onion (Zewde et al., 2018).

Precission agriculture is designed to optimize the use of resources including water and fertilizer. The application of fertigation, where irrigation is combined with fertilizer application is suitable for precision agriculture. Fertilizer is dissolved into irrigation water and dispensed into plant root area. To achieve the best results to support plant growth and high yield, appropriate nutrient dose, amount of water and time for application is essential (Sureshkumar et al., 2016). Plant type and stage of growth, soil conditions, water quality, as well as fertilizer availability and price should be considered when choosing fertilizer for fertigation (Kafkafi \& Tarchitzky, 2011). Fertilizers used should have high purity and solubility with low salt levels and with an acceptable $\mathrm{pH}$. In addition, the cost of fertilizers must fit in the farm management program. To reduce the cost of fertilizer, liquid organic fertilizer can be used in combination with inorganic fertilizer. Application of mix liquid organic fertilizer and AB Mix (50\%:50\%) on tomato using fertigation system yielded tomato with size and weight not significantly different with those treated with $\mathrm{AB}$ Mix (inorganic). Tomato treated with low soil humidity (30\%) produced significantly lighter and smaller fruit weight than those irrigated with higher soil humidity (60\% or $75 \%$ ) (Brotodjojo et al., 2020). As red onion has shallow root zone, providing the appropriate amount of nutrient is critical to achieve maximum growth and high yield. Therefore, this research was conducted to determine the appropriate interval and frequency of nutrient application to produce the highest growth and yield of red onion cultivated under fertigation system. 


\section{RESEARCH METHODOLOGY}

This research was conducted in the Experimental Field of Faculty of Agriculture, Universitaas Pembangunan National "Veteran" Yogyakarta in Wedomartani village, Sleman Regency, Yogyakarta, Indonesia. The location is $113 \mathrm{~m}$ above sea level with the type of soil is regosol. The experiment was set in Split Plot Randomized Completely Block Design with three replicates. The main plots were interval of nutrient application, i.e., 3 days interval, 6 days interval, 9 days interval. The sub plots were the frequency of nutrient application, i.e., once/day, 2 times/day, 3 times/day. The plot size for each treatment was 2.5 $\mathrm{m} \times 1.3 \mathrm{~m}$ and plant spacing was $15 \mathrm{~cm} \times 20 \mathrm{~cm}$. Space between beds was $1 \mathrm{~m}$.

Red onions (Bima variety) were planting in a raised bed covered with silver black polythene mulch. Before planting, 5 ton/ha manure and 1 ton/ha lime were mix with the soil. To control grubs Fipronil $1.5 \%$ was applied with dose $8 \mathrm{~kg} / \mathrm{ha}$. Nutrient was mixture between liquid organic fertilizer 7.5 $\mathrm{mL} / \mathrm{L})$, rabbit urin $(5 \mathrm{~mL} / \mathrm{L})$ and $\mathrm{AB}$ Mix $(7.5 \mathrm{~mL} / \mathrm{L} \mathrm{A}+7.5 \mathrm{~mL} \mathrm{~B})$. The nutrient was dispensed $150 \mathrm{~mL} /$ plant according to treatment using fertigation system operated remotely using Internet of Things. The nutrient was given from 14 DAP (Days After Planting) until 68 DAP. Irrigation water was dispensed $150 \mathrm{~mL}$ daily in the same way. Parameter observed every two weeks on three sample plants were plant height, number of leaves and number of bulbs. Yield (economic weight) was measured after onions were harvested at 75 DAP, sun dried for 5 days and dried leaves were removed. The variance of data was analysed using F test $(\alpha=5 \%)$ followed by Duncan's Multiple Range Test $(\alpha=5 \%)$.

\section{FINDING AND DISCUSSION}

The results showed that fertigation interval and fertigation frequency did not significantly affect plant height at 2 WAP (Weeks After Planting) and 6 WAP. There was an interaction between fertigation interval and fertigation frequency in affecting plant height at 4 WAP, with the highest plant height was resulted from application of nutrient in 3 days interval applied 3 times/day (Table 1). There is no interaction between fertigation interval and fertigation frequency in affecting number of leaves. Fertigation interval at 3 days interval significantly gave the highest number of leave at 2 WAP, 4 WAP, 6 WAP. Fertigation frequency did not significantly affect the number of leaves (Tabel 2). There is no interaction between fertigation interval and fertigation frequency in affecting number of bulbs. Fertigation interval at 3 days interval significantly gave the highest number of bulbs at 2 WAP, 4 WAP, 6 WAP. Fertigation frequency did not significantly affect the number of bulbs (Tabel 3).

Table 1. Plant height of red onion grown with various fertigation interval

\begin{tabular}{ccccc}
\hline $\begin{array}{c}\text { Fertigation } \\
\text { interval }\end{array}$ & $\begin{array}{c}\text { Fertigation } \\
\text { Frequency }\end{array}$ & 2 WAP & 4 WAP & 6 WAP \\
\hline \multirow{2}{*}{3 days } & once/day & $19.6 \mathrm{a}$ & $30.8 \mathrm{a}$ & $31.5 \mathrm{a}$ \\
interval & twice/day & $17.4 \mathrm{a}$ & $28.1 \mathrm{bc}$ & $29.9 \mathrm{a}$ \\
& 3 times/day & $18.9 \mathrm{a}$ & $31.1 \mathrm{a}$ & $33.3 \mathrm{a}$ \\
\hline \multirow{2}{*}{6 days } & once/day & $16.5 \mathrm{a}$ & $28.6 \mathrm{bc}$ & $29.2 \mathrm{a}$ \\
interval & twice/day & $17.7 \mathrm{a}$ & $29.0 \mathrm{ab}$ & $29.4 \mathrm{a}$ \\
& 3 times/day & $20.8 \mathrm{a}$ & $27.6 \mathrm{c}$ & $28.9 \mathrm{a}$ \\
\hline \multirow{2}{*}{9 days } & once/day & $17.7 \mathrm{a}$ & $27.4 \mathrm{bc}$ & $29.8 \mathrm{a}$ \\
interval & twice/day & $17.1 \mathrm{a}$ & $26.7 \mathrm{c}$ & $28.6 \mathrm{a}$ \\
& 3 times/day & $17.2 \mathrm{a}$ & $28.6 \mathrm{bc}$ & $30.7 \mathrm{a}$ \\
\hline Interaction & & - & + & - \\
\hline
\end{tabular}


RSF Conference Series: Engineering and Technology

Vol. 1 (1), 198-203

Growth and Yield Responses of Red Onions to Different Nutrient Availability in Fertigation System

R.R. Rukmowati Brotodjojo, Oktavia S. Padmini, Awang H. Pratomo

The mean followed by the same letter in one column shows no significant difference according to Duncan's Multiple Range Test $(\mathrm{P} \leq 0.05)$; ( - ) indicates that there is no interaction between treatment combinations; $(+)$ indicates that there is an interaction between treatment combinations; WAP: Weeks After Planting

Table 2. Number of leaves of red onion grown with various fertigation interval

\begin{tabular}{|c|c|c|c|}
\hline Treatment & $2 \mathrm{WAP}$ & 4 WAP & $6 \mathrm{WAP}$ \\
\hline \multicolumn{4}{|c|}{ Fertigation interval } \\
\hline 3 days & $7.0 \mathrm{a}$ & $16.3 \mathrm{a}$ & $26.0 \mathrm{a}$ \\
\hline 6 days & $6.4 \mathrm{~b}$ & $14.5 \mathrm{ab}$ & $20.4 \mathrm{~b}$ \\
\hline 9 days & $6.5 \mathrm{ab}$ & $13.3 \mathrm{~b}$ & $19.6 \mathrm{~b}$ \\
\hline \multicolumn{4}{|c|}{ Fertigation Frequency } \\
\hline once/day & $6.5 \mathrm{p}$ & $14.3 \mathrm{p}$ & $21.6 \mathrm{p}$ \\
\hline twice/day & $6.7 \mathrm{p}$ & $15.2 \mathrm{p}$ & $22.4 \mathrm{p}$ \\
\hline 3 times/day & $6.8 \mathrm{p}$ & $14.5 \mathrm{p}$ & $22.0 \mathrm{p}$ \\
\hline Interaction & - & - & - \\
\hline
\end{tabular}

The mean followed by the same letter in one column shows no significant difference according to Duncan's Multiple Range Test $(\mathrm{P} \leq 0.05)$; $(-)$ indicates that there is no interaction between treatment combinations; WAP: Weeks After Planting

Table 3. Number of bulbs of red onion grown with various fertigation interval

\begin{tabular}{|c|c|c|c|}
\hline Treatment & $4 \mathrm{WAP}$ & $6 \mathrm{WAP}$ & $8 \mathrm{WAP}$ \\
\hline \multicolumn{4}{|c|}{ Fertigation interval } \\
\hline 3 days & $4.3 \mathrm{a}$ & $5.3 \mathrm{a}$ & $5.6 \mathrm{a}$ \\
\hline 6 days & $3.7 \mathrm{~b}$ & $4.0 \mathrm{~b}$ & $4.3 \mathrm{~b}$ \\
\hline 9 days & $3.3 \mathrm{~b}$ & $3.9 \mathrm{~b}$ & $4.2 \mathrm{~b}$ \\
\hline \multicolumn{4}{|c|}{ Fertigation Frequency } \\
\hline once/day & $3.7 \mathrm{p}$ & $4.2 \mathrm{p}$ & $4.5 \mathrm{p}$ \\
\hline twice/day & $4.0 \mathrm{p}$ & $4.6 \mathrm{p}$ & $4.9 \mathrm{p}$ \\
\hline 3 times/day & $3.7 \mathrm{p}$ & $4.3 \mathrm{p}$ & $4.7 \mathrm{p}$ \\
\hline Interaction & - & - & - \\
\hline
\end{tabular}

The mean followed by the same letter in one column shows no significant difference according to Duncan's Multiple Range Test $(\mathrm{P} \leq 0.05)$; $(-)$ indicates that there is no interaction between treatment combinations; WAP: Weeks After Planting

There is no interaction between fertigation interval and fertigation frequency in affecting the yield of red onion. Yield of red onion was not significantly affected by fertigation interval. Red onion treated with nutrient 3 times/day significantly produced the highest yield (Tabel 3). 
RSF Conference Series: Engineering and Technology

Vol. 1 (1), 198-203

Growth and Yield Responses of Red Onions to Different Nutrient Availability in Fertigation System

R.R. Rukmowati Brotodjojo, Oktavia S. Padmini, Awang H. Pratomo

Table 4 . Yield of red onion grown with various fertigation interval

\begin{tabular}{|c|c|c|}
\hline Treatment & $\begin{array}{c}\text { Economical } \\
\text { weight } \\
\text { (kg/plot) }\end{array}$ & $\begin{array}{c}\text { Economical } \\
\text { weight }(\mathrm{kg} / \mathrm{ha})\end{array}$ \\
\hline \multicolumn{3}{|c|}{ Fertigation interval } \\
\hline 3 days & $11.88 \mathrm{a}$ & $21,938 \mathrm{a}$ \\
\hline 6 days & $11.57 \mathrm{a}$ & $21,352 \mathrm{a}$ \\
\hline 9 days & $12.03 \mathrm{a}$ & $22,213 \mathrm{a}$ \\
\hline \multicolumn{3}{|c|}{ Fertigation Frequency } \\
\hline once/day & $11.85 \mathrm{a}$ & $21,875 \mathrm{a}$ \\
\hline twice/day & $11.47 \mathrm{a}$ & 21,167 a \\
\hline \multicolumn{3}{|l|}{3} \\
\hline times/day & $12.18 \mathrm{~b}$ & $22,490 \mathrm{~b}$ \\
\hline Interaction & - & - \\
\hline
\end{tabular}

The mean followed by the same letter in one column shows no significant difference according to Duncan's Multiple Range Test $(\mathrm{P} \leq 0.05)$; $(-)$ indicates that there is no interaction between treatment combinations; WAP: Weeks After Planting.

These results indicated that red onion growth was mainly affected by interval of fertigation. With 3 days interval, plant will receive more nutrient than those treated with 6 days or 9 days interval, regardless the daily frequency of the application. With more nutrient supply, red onion can grow higher, produced more leaves and more bulbs. However, the yield was affected more by the frequency of daily nutrient supply. The nutrient that was replenished 3 times/day were more effectivey absorbed by the root of red onion that grow on the upper part of soil. The nutrient that was dispensed once/day or twice/day most likely flowed down the ground, because regosol soil cannot hold water for long time. Meanwhile, red onion has short root that can only reach nutrient that available in the sub surface of soil. The yield obtained from this study $(21,167 \mathrm{~kg}-22,490 \mathrm{~kg})$ in general is much higher than the yield of variety description for Bima variety, which is 9,9 ton/ha dry weight (Balitsa, 2018). This could be because the red onion was fertilised until 68 DAP and harvested at 75 DAP, which is much longer than recommended (60 DAP). The extension of fertigation period provides more nutrient for plant that has been used for bulbs development.

\section{CONCLUSION AND FURTHER RESEARCH}

The interval of fertigation significantly affected the growth of red onion (plant height, number of leaves and number of yield). Three days interval of nutrient supply resulted in the tallest plant, highest number of plant leaves, and highest number of bulbs. However, the frequency of nutrient supply daily significantly affected the yield of red onion. The application of nutrient three times/day provided the highest yield (economical dry weight). Further research to examine the effect of fertigation of red onion quality is needed.

\section{Acknowledgments}

The authors would like to thank the Ministry of education, Culture, Research and Technology that provided research funding through the Higher Education Applied Research grants (Grant Contract No. 294/E4.1/AK.04.PT/2021) and to the Institute for Research and Community Services Universitas Pembangunan Nasional Veteran Yogyakarta that manage the grant funds (Contract No.95/UN62.21/PT/VII/2021). 


\section{REFERENCES}

Badan Pusat Statistik, 2021. Produksi Sayuran 2018-2020. Downloaded from https://www.bps.go.id/indicator/55/61/3/produksi-tanaman-sayuran.html.

Balitsa, 2018. Deskripsi Bawang Merah Varietas Bima Brebes. Downloaded from https://balitsa.litbang.pertanian.go.id/ind/index.php/varietas/cabai/36-halaman/616bawang-merah-varietas-bima-brebes.

Balittanah 2006. Pupuk Organik dan Pupuk Hayati (Organicm Fertilizer and Biofertilizer). Balai Besar Litbang Sumberdaya Lahan Pertanian Badan Penelitian dan Pengembangan Pertanian. Bogor.

Brotodjojo, R.R.R. \& Arbiwati, D. 2017. Application of Granular Organic Fertilizer to Improve Yield of Red Onion. International Journal of Advances in Agricultural \& Environmental Engineering (IJAAEE) $4(1): 89-92$.

Brotodjojo, R.R.R., Padmini, O.S. \& Pratomo, A.H. 2020. The Effect of Various Fertilizer Application and Soil Humidity on The Quality of Tomato. Proceeding International Conference on Green Agro-Industry, $4:$ 215-222. http://eprints.upnyk.ac.id/23270/

Hu, J., Gettel, G., Fan, Z., Haofeng Lv, Zhao, Y., Yu, Y., Wang, J., Butterbach-Bahl, K., Li, G., Lin, S. 2021. Drip fertigation promotes water and nitrogen use efficiency and yield stability through improved root growth for tomatoes in plastic greenhouse production. Agriculture, Ecosystems \& Environment, 313. https://doi.org/10.1016/j.agee.2021.107379.

Kafkafi, U. \& Tarchitzky, J, 2011. Fertigation: A Tool for Efficient Fertilizer and Water Management. International Fertilizer Industry Association (IFA). International Potash Institute (IPI) Paris., France.141p.

Kumar, S., Imtiyaz, M., Kumar, A. 2007. Effect of differential soil moisture and nutrient regimes on postharvest attributes of onion (Allium cepa L.), Scientia Horticulturae 112 (2): 121-129.

Lawlor, D.W. 2002. Carbon and nitrogen assimilation in relation to yield: mechanisms are the key to understanding production systems. Journa of Experimental Botany 53 (370): 773-787.

Ministry of Trade, 2021. Analisis Perkembangan Harga Pangan Pokok di Pasar Domestik dan Internasional. Ministry of Trade, The Republic of Indonesia. Downloaded from http://bppp.kemendag.go.id/media_content/2021/03/Analisis_Bapok_Bulan_Februari_2021.pd f.

Simonne, E.H., M.D. Dukes, \& L. Zotarelli. 2010. Principles and Practices of Irrigation Management for Vegetables. Chapter 3. IFAS Extension. Florida.

Sureshkumar, P., Geetha, P., Narayanan Kutty, M.C., Narayanan Kutty, C. \& Pradeepkumar, T. 2016. Fertigation - the key component of precision farming. Journal of Tropical Agriculture 54 (2) : 103114.

Vachan, R. \& Tripathi, S.M. 2017. Study on the effect of bio-fertilizer with chemical fertilizer on plant growth, Yield and economics of Rabi season onion (Allium cepa L.) cv. NHRDF Red 2. Journal of Pharmacognosy and Phytochemistry 6(5): 1496-1499.

Vance, C.P., Uhde-Stone, C., Allan, D.L 2003. Phosphorus acquisition and use: critical adaptations by plants for securing a nonrenewable resource. New Phytologist 157: 423-447,

Wang, M., Zheng, Q., Shen, Q. \& Guo, S. 2013. The Critical Role of Potassium in Plant Stress Response. International Journal of Molecular Science 14: 7370-7390.

Zewde, A., Mulatu, A. \& Astatkie, T. 2018. Inorganic and Organic Liquid Fertilizer Effects on Growth and Yield of Onion, International Journal of Vegetable Science, 24:6, 567573, DOI: $10.1080 / 19315260.2018 .1453572$. 